\title{
ENCODING THE PLURAL-HONORIFIC SUFFIX -ANI AND THE IMPERFECTIVE ANGA IN MALAWIAN CITONGA (N.15) ${ }^{1}$
}

\author{
Winfred Mkochi \\ University of Malawi
}

\begin{abstract}
Many Bantu languages have the plural-honorific suffix $*$-Vni and the imperfective morpheme $*_{-} a(n) g$-. In most of these languages, $*_{-V n i}$ is reported to be clearly encoded at POST-FINAL position. On the other hand, $*_{-} a(n) g$ - is said to be ambiguously encoded, either at EXT (extension) in one language or FV (final vowel) in another language. Still in others it coexists at both EXT and FV; there has also been a suggestion that it is encoded at POST-FINAL in several others. This article argues that the status of both the pluralhonorific suffix -ani (*-Vni) and the imperfective -anga $(*-a(n) g)$ - in CiTonga is fluid, it prevaricates between EXTENSION (suffix), FV (the commonest), and POST-FINAL (clitic). Although these formatives can be encoded at these positions, they are shown to be functionally different from extensions, inflectional vowel suffixes and clitics.
\end{abstract}

Keywords: Bantu, Malawian Tonga, verb structure, plural-honorific suffix *-Vni, imperfective ${ }^{*}$-a(n)g-.

\section{Introduction}

Malawian Tonga ${ }^{2}$ (henceforth CiTonga) is a Bantu language classified by Guthrie (1948) as belonging to Zone N (Group 10) together with the neighboring Chichewa (N.30) and CiTumbuka (N.20). It is the main language of the Tonga ethnic group and it is mainly spoken in Nkhata Bay District of northern Malawi and some parts of Mzimba and Nkhotakota Districts which share borders with it. To our knowledge, this is the first work to examine the structural properties and functions of the plural-honorific suffix -ani and the imperfective -anga in this language.

Note that most verbs in Bantu languages are made up of a stem and a string of prefixes and suffixes. Meeussen (1967) proposed a template of its structure which has undergone revisions together with the changes in terminology. The result is the linear structure given roughly in (1) below:

(1) $\quad$ Pre-SM + SM + NEG2 + TA + OM + root + extension + FV + post-FV

Since the 1970's, however, there has been a growing view that the inflected verb has a hierarchical structure (see Cheng and Kisseberth 1979, 1980, 1981; Myers 1987, 1990, 1997, 1998; Hyman 1989, 2007, 2008, 2009; Mutaka 1994; Odden 1996; and Downing 2001). Evidence for the hierarchical structure has been drawn from prosodic processes such as high tone assignment for the macrostem, vowel harmony for the derivational stem, and nasal harmony, reduplication, and vowel

\footnotetext{
${ }^{1}$ I would like to acknowledge significant input from Lee Bickmore, Atikonda Mtenje-Mkochi and two anonymous reviewers. This research was fully supported by a research Fulbright Grant (IIE \# PS00267377). Any errors or omissions are entirely my own.

${ }^{2}$ The population of CiTonga speakers in 2008 was estimated at 1.7\% of Malawi's 13.1 million people (2008 Malawi Housing and Population Census, National Statistical Office). It is not the same language as Zambian Tonga (M.64) studied by, for example, Goldsmith (1984), and the two languages are not mutually intelligible.
} 
coalescence for the inflected stem. This hierarchical structure is roughly represented in (2) below (the Post-FV is usually not featured).

$$
\begin{aligned}
& \mathrm{INFL}+[\mathrm{OM}+[[\text { root }+ \text { extension }]+\mathrm{FV}]]+\text { Post FV (Adapted from Nurse } \\
& \text { 2008:42) }
\end{aligned}
$$

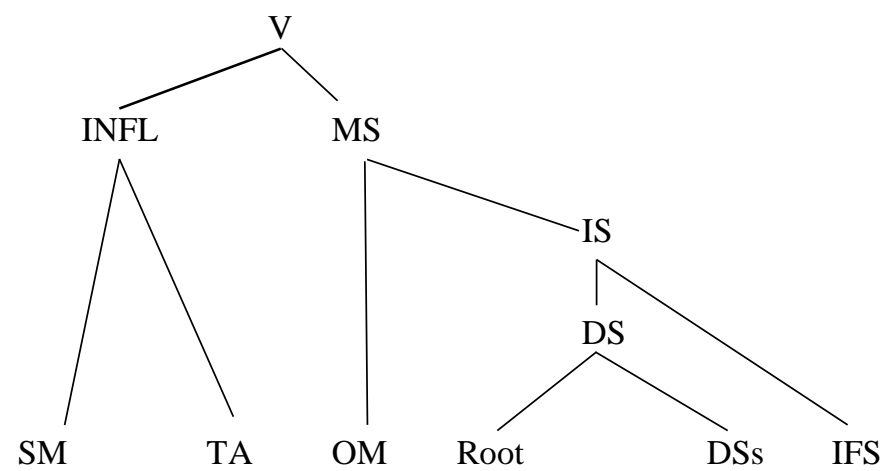

Among others, the INFL consists of the SM and TA. The object marker ${ }^{3}$ and the inflected verb dstem constitute the macrostem which combines with all the INFL morphemes to its left to form the verbal word. The inflected verb stem (IS) comprises of the derivational stem (DS) and an inflectional final suffix (IFS) $-a$ or its subjunctive counterpart $-\mathrm{i}$ or $-e$ (among other final suffixes). ${ }^{4}$ The inflectional final suffixes are encoded at FV and they express neutral/indicative and subjunctive moods, respectively. Finally, the derivational stem is made up of the root and one or more derivational suffixes (DSs) (extensions) marking operations like the passive, the applicative, and the reciprocal.

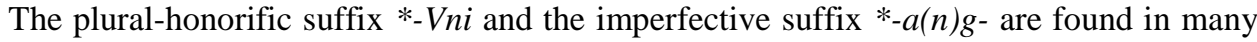
Bantu languages and, as reported by Nurse (2008), *-Vni occurs widely at post-final position (roughly, after the FV position), while - *a(n)g-is encoded at EXT(extension) or FV (which includes pre-final) or, ambiguously, at both EXT and FV (see also Bernander 2017; Nurse and Philippson 2006). ${ }^{5}$ The formative -ani is referred to as being honorific because it is also used when addressing people of higher status, older people (including older relatives) and one's husband. It is referred to as plural because it is also used when addressing two or more people. As an understudied language, there has been no previous study on the status of -ani and -anga in CiTonga. In this article, we argue that the status of both of them is fluid, it prevaricates between EXT(ension) FV and POST-FINAL (clitic), although FV is the commonest.

CiTonga lost contrastive vowel length. Length, however, is realized on the penultimate syllable of phonological phrases. We do not mark length in this paper. The language has two level tones, High (marked by an acute accent) and Low (not marked). Vowel roots are either toneless or High-toned underlyingly and the Low tone is introduced at the very end of the phonology onto the tone bearing units. All imperatives (without OM) in CiTonga surface without a High tone (see Bickmore and Mkochi 2018; and forthcoming).

\footnotetext{
${ }^{3}$ Only one object prefix (or reflexive prefix) is allowed per verbal word in CiTonga.

${ }^{4}$ Note that the vowels /u/ and /i/ in this language are optionally lowered to /o/ and /e/ at phrase-final positions.

${ }^{5}$ Note that Meeussen (1967) and Sebasoni (1967) posit that $*_{-a g} / *_{-}$ang is neither extension nor FV, but occupies a specific slot in the verbal form, i.e. prefinal or in between the extensions and the FV (see also Guldemann 1999; Bernander 2017:151). In this paper, we follow Nurse and Philippson (2006), among others, in assuming that the pre-final -ag-/-ang- is an FV in some languages and that it is an FV that combines with other FVs (Nurse and Philippson 2006:191).
} 
The author is a native speaker of CiTonga and thus primary source of the data. The paper is organized as follows: Sections $2 \& 3$ present an overview of the plural-honorific suffix -ani and the imperfective -ang-in CiTonga. Sections $4 \& 5$ present arguments for the positions taken here. And Section 6 concludes the paper.

\section{An overview of the plural-honorific suffix -ani}

The plural-honorific suffix reconstructed as $*$-Vni for Proto-Bantu (also known as plural addressee marker (Devos and van Olmen (2013)) is one of the suffixes that are reported to be commonly found at the post-final position of Bantu verbs. The others include negation, different degrees of time, location, pronominal objects, interrogatives (Wh-forms), and relativizers (Nurse 2008). Nurse (2008) reports that subject markers can also occur at post-final in relativized forms in certain languages. He suggests that all this material had started their early lives as independent post-verbal elements.

The Proto-Bantu *-Vni started as an independent second person plural pronoun (Nurse 2008; Van de Velde and van der Auwera (2010: 137; Devos and Van Olmen (2013)) ${ }^{6}$. According to Nurse (2008:277), it is the only post-final "with truly Bantu-wide distribution". It is found in all Zones, except Zone $F$ where instead they have suffixal $-i$ (Nurse 2008: 39, 277). Nurse further reports that the shape -(e)ni is the commonest, but other forms such as "-enu, -inu, -anu (or [o] for $[\mathrm{u}])$ and $-(V) n a$ " are also found, mainly in the Forest languages. It is glossed by Meeussen (1967) as "plural suffix" and by Guthrie (1967) as "plural suffix in verbal interjections". Nurse (2008: 39) reports that it occurs mainly in second person plural imperatives, but it occurs also with person plurals, plural addressees, and non-imperatives. According to Nurse (2008: 56-57), this morpheme is "clearly a clitic".

In this article, the term "plural-honorific suffix" is used. In CiTonga it is used in plural imperatives and non-imperatives involving second person plural/honorific pronouns (to be exemplified further below).

Singular/non-honorific imperatives in this language consist of an inflected verb stem with the neutral final vowel $-a$ as given in the forms without the OM in (3) below. Note that the imperatives with object pronouns appear to have a "subjunctive" form. Strictly speaking, though, these constructions are not subjunctive forms. The (minimal) common Bantu subjunctive form, also reconstructed to PB, is SM-Root-e (cf. Meeussen 2014). The forms in (3) do not correspond to this form as they do not have a SM. These are common Bantu imperatives whose minimal form is Roota. The FV of the imperative commonly shifts to $-i$ (or optionally lowered to -e in phrase-final positions) when it takes an OM. The suffix $-i$ is therefore glossed here as IMP(erative).

\begin{tabular}{|c|c|}
\hline Singular imperatives & \\
\hline Without OM & With OM \\
\hline a. bik-a & mu-bík-i \\
\hline cook-FV & 1OM-cook-IMP \\
\hline 'cook!' & 'beat him/her up!' \\
\hline b. bik-isy-a & mu-bik-ísy-i \\
\hline cook-CAUS-FV & 1OM-cook-CAUS-IMP \\
\hline 'cause to cook!' & 'cause him/her to cook!' \\
\hline c. vin-a & mu-vín-i \\
\hline dance-FV & 1OM-dance-IMP \\
\hline 'dance!' & 'initiate him/her!' \\
\hline
\end{tabular}

\footnotetext{
${ }^{6}$ Devos and Van Olmen (2013), however, suggest that there is need for more research, including outside Bantu, to ascertain the origin of the plural addressee marker.
} 
The data in (3) above show that singular/non-honorific imperatives are not marked suffixally beyond the FV.

The negative counterparts (meaning "do not X") are formed by adding an independent negative clitic cáa after them (e.g. bika cáa 'don't cook/not cook'). The commonest way to form negative imperatives, however, is using a softer command with the infinitive form plus the independent negation particle cáa. A similar pattern is found in other $\mathrm{N}$ languages such as Kindendeule (N.101) and Chingoni (N.12) studied by Ngonyani (2013) and CiTumbuka (N21, Vail 1973). Such constructions could mean 'to not $X$ ', i.e. rendering the negative imperative more polite (cf. Devos \& Van Olmen 2013) than the ones without $k u-$.

We illustrate this fact in (4) below.

(4) Negative imperatives with infinitive $k u$ -

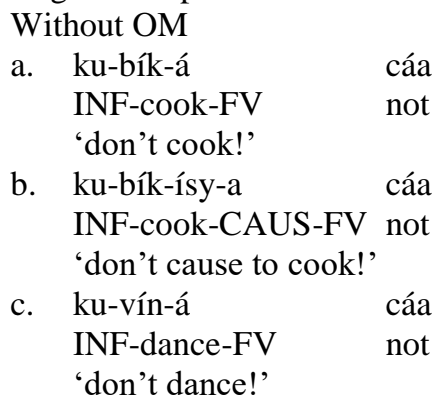

$\begin{array}{lll}\text { With OM } & & \\ \text { ku-mu-bík-á } & \text { cáa } & \\ \text { INF-1OM-cook-FV not } & \\ \text { 'don't beat him/her up!' } & & \\ \text { ku-mu-bík-ísy-a } & & \text { cáa } \\ \text { INF-1OM-cook-CAUS-FV } & \text { not } \\ \text { 'don't cause him/her to cook!' } & \\ \text { ku-mu-vín-á rán } & \\ \text { INF-1OM-dance-FV not } & \\ \text { 'don't initiate him/her!' } & & \end{array}$

Examples in (5a-d) show imperative constructions marked with the plural-honorific suffix -ani. Examples in (5d-e) show that their negative counterparts are usually the same as those for singular imperatives. When the infinitive marker $k u$ - is used, however, -ani is absent (5e). Examples in (5f) show that where both $k u$ - and -ani are preserved, we get ungrammatical forms.
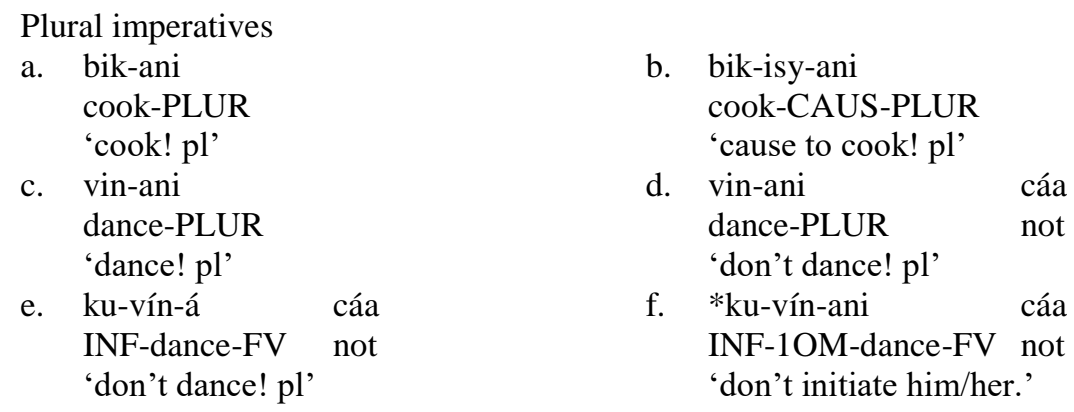

One crucial observation about the data in (5a-d) above is that they show -ani in a position usually associated with inflectional final vowels.

We present in (6a) below non-imperatives (finite forms) involving singular-non-honorific object pronoun - $k u$ - where -ani does not appear. When the object pronoun is in plural-honorific mode (e.g. - $m u$-), however, -ani appears in the verb complex as in (6b). We show in ((6b)(iv)) that -ani- is realized as -eni when it is in a subjunctive sort of construction.

Plural-honorific suffix -ani co-occurs with 'plural-honorific' OM
a. With singular $(2 \mathrm{sg}) \mathrm{OM}$
(i) ti-ngu-ku-bík-a we-PST-you(sg)-cook-FV
'we beat you up, sg'
b. With plural-honorific (2pl) OM
(i) ti-ngu-mu-bík-ani we-PST-you(pl)-cook-PLUR 'we beat you up, pl'



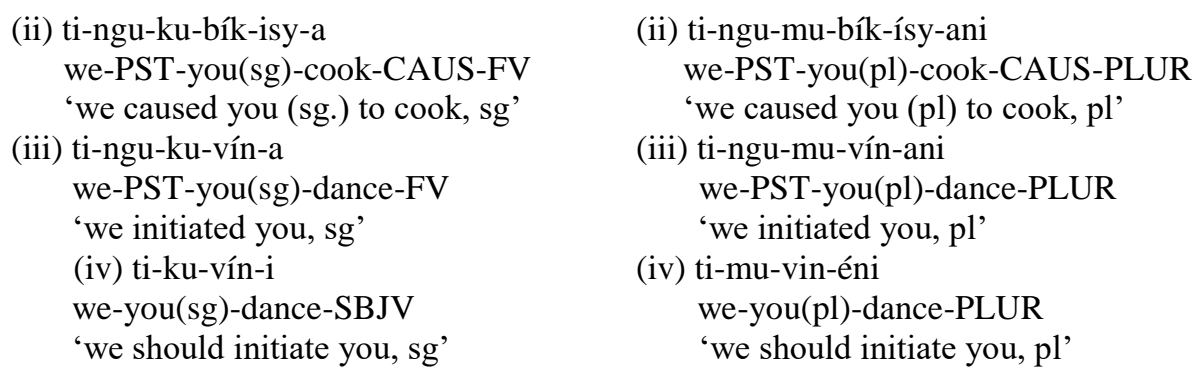

Our explanation for the realization of -ani as -eni is that, besides vowel height harmony (to be exemplified further below), CiTonga has a rare trait of regressive vowel front-ness harmony and it is triggered by the subjunctive vowel /i/. Thus, the correct morpheme analysis of ((6b)(iv)) above is revised in (7) below. ${ }^{7}$

$$
\begin{aligned}
& \text { ti-mu-vin-en(i)-i } \\
& \text { we-you(pl)-dance-PLUR-SBJV }
\end{aligned}
$$

Note that -ani can also appear in the forms with the second person object pronoun $-k u$ - as illustrated in (8) below, only that $-m u$ - is more honorific than $-k u$-.

(8) Plural-honorific -ne may also co-occur with second person pronoun - $k u$ -
a. ti-ngu-ku-bík-ani
'we beat you up, pl'
b. ti-ngu-ku-bík-ísy-ani
'we caused you to cook, pl'
c. ti-ngu-ku-vín-ani
'we initiated you, pl'
d. ti-ku-vin-en(i)-i
'we should initiate you, pl'

The data in (6) and (8) show that $-k u$ - can be used to indicate both singular and plural verb forms. The explanation for this could be that $-k u$ - is used in both singular and plural object pronoun forms (or it is neutral in terms of number). The second person object pronoun - $m u$-, however, is always used as a plural form. Therefore, without the -ani, the non-imperative forms with the second person plural object pronoun in (6b) would sound ungrammatical or mean something different (e.g. *ti$n g u-m u-b i k-a$, or it would mean 'we beat him/her up').

Finally, we have observed in this language that -ani does not follow the first person object pronouns -ndi- and -ti- (e.g. wa-ngu-ti-púum-a 'he beat us up' vs. *wa-ngu-ti-púm-(a)-ani), nor the third persons -mu- and -va- (e.g. ti-ngu-va-púum-a 'we beat them up' vs. *ti-ngu-va-púm-(a)-ani). We have also observed that -ani never occurs with second person subject pronouns in finite forms (e.g. mu-ngu-biik-a 'you cooked' and not *mu-ngu-bik-(a)-ani).

\section{An overview of the imperfective -anga}

A formative of the shape -a(n)g- is found in all Bantu zones, except R (Nurse and Philippson 2006). According to Nurse and Philippson (2006), within the R zone, it is R41 which seems not to have it (citing Sommer 2003:578). It occurs in 69\% of the 100 languages studied by Nurse and Philippson. It is lost, among others, in a large southeastern area involving most of M40-50-60, most of N, parts of P20 and much of S. CiTonga (N15), therefore, is among few N languages where the formative is still found.

\footnotetext{
${ }^{7}$ One other possible explanation is that the underlying form has a final subjunctive (lowered) vowel -e between the verb root and -ani (i.e. /ti-mu-vin-e-ani/) and $\mathrm{V}_{2}$ deletion results into an output [ti-mu-vin-e-(a)ni]. This explanation, however, would not account for all the scenarios where -ani is realized as -eni and, below, -anga as -engi. Furthermore, it is very unlikely that the subjunctive form would be $-e$ in a non-phrase-final position.
} 
According to Nurse and Philippson (2006), within Bantu this formative has two shapes, $a g$ - and -ang-. The most widespread is -ag- while -ang-occurs only in Groups B30, D10, D40, E15 Ganda, E30-40, E55 Kamba, H10, H40, all K except K20, all L, M10, and N21 Tumbuka. Sebasoni (1967:131), on the other hand, states that there are three allomorphs of this suffix that are more or less in complementary distribution. He says "... -ag- is predominantly found in the north-east and east of the Bantu domain, -ak- in the north, -ang- in the west and south".

In CiTonga, the shape of this formative is -anga, and like in many Bantu languages, it is tonally low. CiTonga therefore is among a few Bantu languages that have the $-a(n) g-(a)$ shape. The shape -a(n)g- is widespread in Bantu and it is also found outside Bantu (Nurse and Philippson 2006:192). It is because of its widespread distribution that it is also reconstructed for Proto-Bantu and earlier in Niger-Congo.

In terms of meaning, it typically refers to a range of imperfective aspect meanings which include imperfective itself, progressive, iterative, habitual and pluractional (see Devos ad Olman 2013). By definition, imperfective is used here as "a broad aspectual category to indicate that the viewpoint is on the internal structure of a situation" (Bernander 2017:180; See also Bybee et al. 1994:137-139; Comrie 1976:24-40). Occasionally, it has extended to past and future tense reference. It is mostly found in non-finite forms such as imperative and infinitive (Nurse and Philippson 2006: 190).

The imperfective -anga in CiTonga is found in both the imperative and a number of nonimperative tense-aspects (where it can have different referents). These include "be 'X-ing", "habitual", "progressive", "continuous", and "near future" as shown by the English glosses in the examples in (9). This formative, it seems, is purely inflectional, and not derivational, in CiTonga.

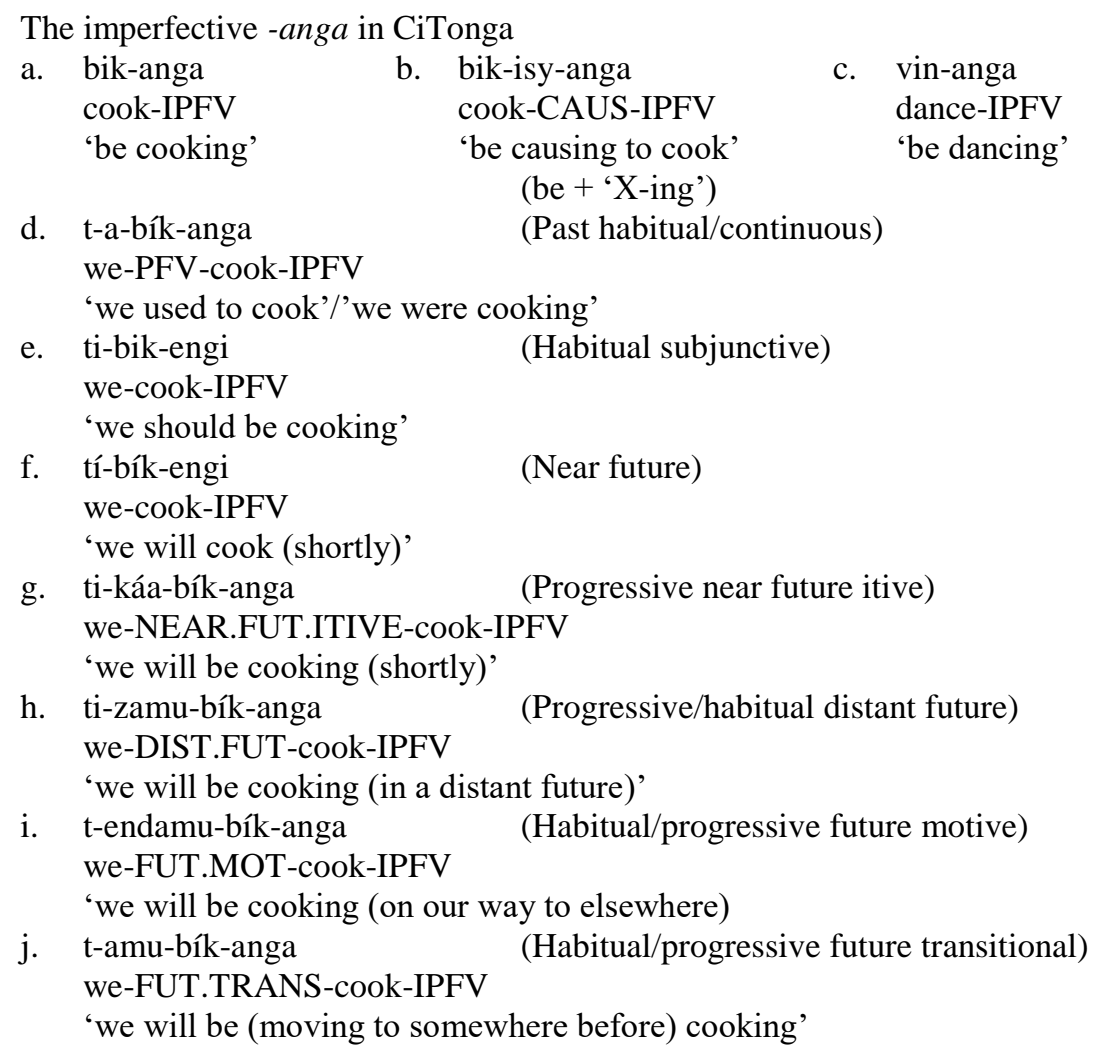

We propose an underlying form with a subjunctive suffix $-i$ for the forms in (9e) and (9f) above in order to account for the realization of -anga as -engi. 

a. /ti-bik-enga-i// $\quad>\quad$ ti-bik-eng(a)-i we-cook-IPFV-SBJV
b. /tí-bík-enga-i/l >í-bík-eng(a)-i we-cook-IPFV-SBJV

Thus, just like with -ani/-eni, we propose that the realization of -anga as -eng(a)- $i$ is as a result of regressive vowel front-ness harmony. Another crucial observation is that just like -ani, -anga is at a position usually associated with final vowel suffixes.

Internal and comparative factors suggest that the reconstructed Proto-Bantu *-a(n)gsurfaced in a pre-final position just before the final suffixes (Meeussen 1967; Sebasoni 1967; Guldemann 1999; Nurse and Philippson 2006:190; Devos and Olmen 2013:8). Nurse and Philippson suggests that this pre-final suffix has its origins from a repetitive derivational extension (see also Schadeberg 2003). The pre-final slot is, arguably, not present in some languages (e.g. Manda Bernander 2017:151). We believe the same thing can be said about CiTonga and, as a result, it is not represented in the verb template we have assumed here.

In literature -a(n)g- has productively been associated with three positions: FV, EXT(ension) and POST-FINAL. For example, Nurse (2008:276) resolves that " * $*_{-} a$ 'neutral', * $e$ 'subjunctive', *-a(n)g- 'habitual/iterative, and *-i(le) 'anterior" can be assumed for Proto-Bantu as morphemes at FV. He suggests that it is most likely that Proto-Bantu allowed $*_{-} a(n) g$ - to combine with the other three FV morphemes (see also Guthrie 1971, \& Meeussen 1967). In its modern use, $*_{-} a(n) g$ - has ambiguous behavior as it characteristically behaves as a member of EXT in some languages, but FV in others (Nurse 2008: 37). Still in some languages, e.g. Bena (Nurse 2008) in (11) below, it coexists in both EXT and FV. ${ }^{8}$

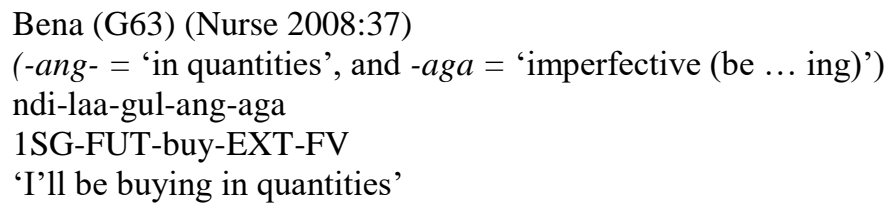

Rugemalira (2010) settles for affix and clitic in several other Bantu languages as the status of a(n)g-. He suggests that the form with a -VNC- structure is an affix in the verb extension system (e.g. in Swahili and Sumbwa). A form with the (N)CV structure is a clitic (e.g. in Nyambo and colloquial Swahili). The following section discusses co-occurrence relations between -ani and anga in CiTonga.

\section{Co-occurrence patterns between -ani and -anga}

We present in this section two co-occurrence patterns between the plural-honorific suffix -ani and the imperfective -anga when they are both present in the verb complex. The two formatives can be freely re-ordered. The first pattern, exemplified in (12) below, shows that -ani can precede -anga. ${ }^{9}$

\footnotetext{
${ }^{8}$ Note that Nurse (2008) does not discuss the diagnostics for determining whether $-a(n) g$ - is better categorized as EXT or FV. We may assume, however, that in a language where - $a(n) g$ - can either precede or follow other extensions, then it's diagnosed as being in the EXT slot, whereas in a language where it's always immediately preceding the FV, it could be analyzed as being in the FV (which includes Meeussen's (1967) pre-final slot (Nurse 2008:130; Bernander 2017: 182; Nurse and Philippson 2006: 190-191; see also Sebason 1967)). In the latter case it should be said that it doesn't stand alone in that slot, but it is followed within that slot by another FV /-V/ (Nurse and Philippson 2006:191). (Of course, even if it is always adjacent to the FV, it is not actually clear to us why it could not be an EXT, specified as the very last EXT, as it is a known fact that some languages exhibit ordering constraints.)

${ }^{9}$ Note that there is no reflex of -ile in CiTonga.
} 


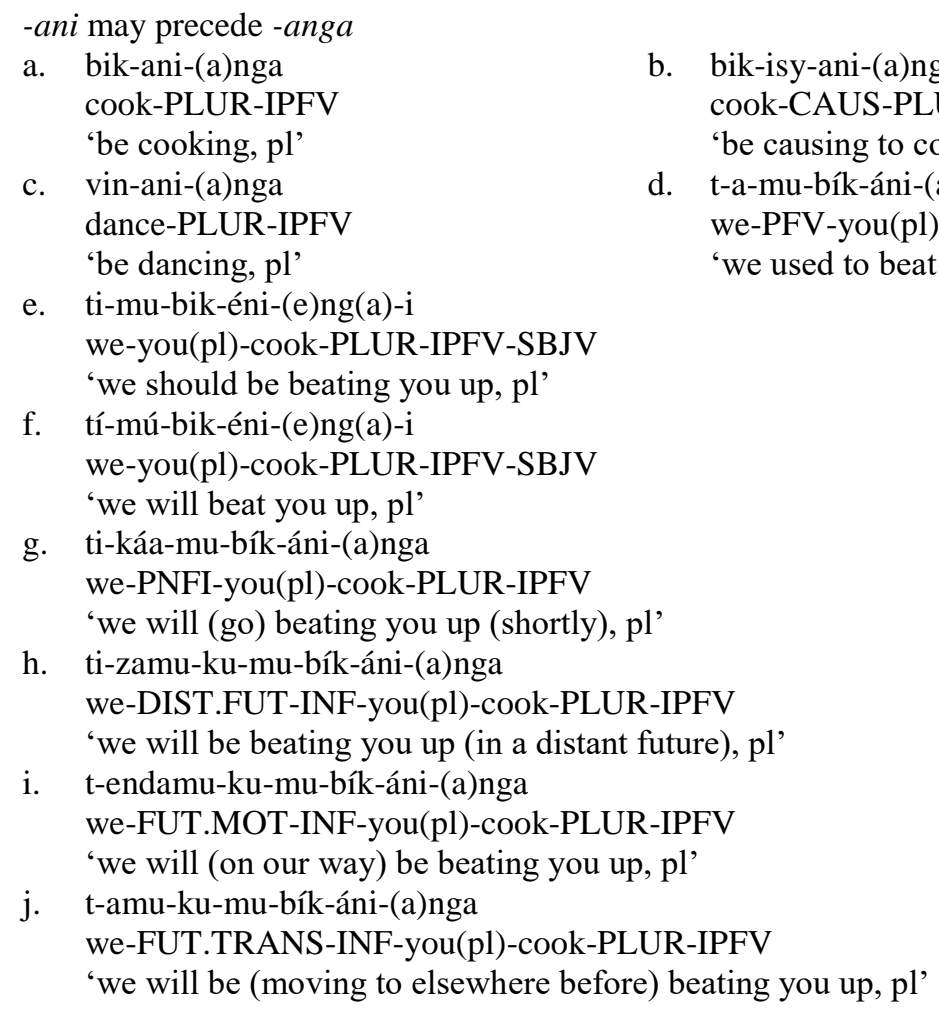

The data in (12) above show that $\mathrm{V}_{2}$ is deleted when -anga follows -ani (i.e. -ani-(a)nga). This is quite different from a scenario where the subjunctive suffix $-i$ followed -ani or -anga in the previous sections. It was $\mathrm{V}_{1}$ that was deleted (i.e. an $(i)-i$ and $\left.-a n g(a)-i\right)$. This is an indication that -ani and ang $a$ are functionally different from the inflectional final vowel suffixes. Crucially, in (12e\&f), we see regressive vowel harmony, triggered by the subjunctive suffix - $i$, applying on both -anga and ani which are now realized as -eni and -engi. Since -eni and -engi clearly precede the final vowel (as illustrated by the subjunctive), this type of harmony can never be progressive.

We now move to the second pattern. The data in (13) below show that the plural-honorific suffix -ani can also follow -anga. Examples in (13e\&f) show that regressive harmony triggered by the subjunctive $-i$ also applies to both -anga and -ani .
-anga may precede -ani
a. bik-anga-(a)ni
b. bik-isy-anga-(a)ni
c. vin-anga-(a)ni
d. t-a-mu-bík-ánga-(a)ni
e. tí-mú-bik-énge-(e)n(i)-i
f. ti-mu-bik-enge-(e)n(i)-i
g. ti-káa-mu-bík-ánga-(a)ni
h. ti-zamu-ku-mu-bík-ánga-(a)ni
i. t-endamu-kumu-bík-ánga-(a)ni
j. t-amu-ku-mu-bík-ánga-(a)ni
'be cooking, pl'
'be causing to cook, pl'
'be dancing, pl'
'we used to/were beating you up, pl'
'we will beat you up (in near.fut.) pl'
'we should be beating you up, pl'
'we will (go) be beating you up, pl'
'we will be beating you up (in dist.fut), pl'
'we will (on our way) be beating you up, pl'
'we will be (moving elsewhere) beating you up, pl'

We propose that -ani and -anga are commonly encoded at FV in all the data presented so far, although they are functionally different from the inflectional final vowels. Our evidence is based on 
the regressive vowel harmony which does not extend to roots such as -mat- and extensions such as the reciprocal -an- as illustrated in (14) below.

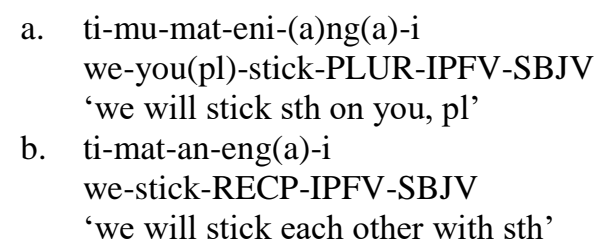

The data in (14a) and (14b) show that the front-ness vowel harmony triggered by the subjunctive vowel /i/ applies to both -ani and -anga. However, the front-ness feature does not spread to the root -mat- or the reciprocal -an-, an indication that -ani and -anga are also functionally different from extensions and roots.

The plural-honorific suffix -ani in CiTonga, therefore, is encoded differently from the neighboring Chichewa (Stevick and Hollander 1965:17) where it is encoded at POST-FINAL (clitic) only. So far the encoding of -anga in CiTonga behaves like in CiTumbuka, a neighboring and closely related language, where $-a(n) g-a$ is also encoded at FV. ${ }^{10}$ Nurse (2008: 38) reports that in CiTumbuka the imperfective " $-a(n) g-a$ " is encoded at FV as given in (15) below. Note that the glossing (or the absence of it), in (15), is given exactly the way it is presented in Nurge (2008:38). There are no interlinear glosses for (15a) and (15d), and -anga is presented as one morpheme in $(15 \mathrm{c})$, while -eng-e is presented as two morphemes in (15d).

$$
\begin{aligned}
& \text { The encoding of } a(n) g \text { - in CiTumbuka (Nurse 2008: 38) } \\
& \begin{array}{ll}
\begin{array}{l}
\text { a. t-a-timb-a } \\
\text { b. ti-(ka)-tol-e }
\end{array} & \text { 'we have struck (today)' } \\
\text { we-(Itive)-take-SBJV } & \text { 'let's (go and) take' } \\
\text { c. t-a-timb-anga } & \text { 'we were striking (today) } \\
\text { we-PST-strike-IPFV } & \text { 'we will go' (/-ang-e/) } \\
\text { d. ti-lut-eng-e }
\end{array}
\end{aligned}
$$

The data in (15a) and (15b) above illustrate the CiTumbuka inflected verb words in neutral and subjunctive forms, respectively. The forms in (15c) and (15d) show that the past progressive and the near future are marked by the imperfective -anga (and -enge in the subjunctive). In both cases, the imperfective -anga/-enge is said to be encoded at FV. In the following section we show that the status of -ani and -anga in CiTonga is, however, fluid as it occasionally prevaricates between EXT (suffix), FV and POST-FINAL (clitic).

\section{Fluidity of the status of -ani and -anga}

From the data presented so far we have suggested that -ani and -anga in CiTonga are slotted at the FV (FINAL) position. We suggest in this section that -ani and -anga can, occasionally, also be encoded at POST-FINAL and EXT. This state of affairs is supported by the fact that these formatives can be freely ordered with the well-known post-final categories and extensions.

\footnotetext{
${ }^{10}$ CiTumbuka and CiTonga share a lot, especially morphologically. In fact, CiTonga was regarded as a dialect of CiTumbuka in colonial literature (Bryan, 1959; Tew, 1950). Bryan places CiTumbuka and CiTonga in one group, CiTumbuka Single Unit. The language is also described by Turner (1952) as being like CiTumbuka in terms of shared lexical items. In the Glottolog, a comprehensive online bibliographic database for the world's languages, mainly the little-known ones, CiTonga is listed along CiTumbuka under the group Tumbukic (2) (Hammarström, Forkel and Haspelmath (2018)).
} 
In modern Bantu languages, some of the morphemes that are encoded at the post-final position include locatives, object pronouns, focus, aspect, and tense (Nurse 2008: 39). We here discuss locatives (-pu, $-k u$, and - $m u$ corresponding with noun classes 16, 17 and 18), the interrogative $-n j i$, and the morpheme $-d i$ (which means 'really [do X]'11).

To begin with, note that the locatives, -nji and -di can co-occur without having any fixed order (but the meaning remains the same). This assertion is illustrated in (16) below.

$$
\begin{array}{ll}
\text { Locatives, - } n j i \text { and - } d i \text { "really" can be re-ordered } \\
\text { With LOC - } p u & \text { With LOC - } k \\
\text { ('really cook what on there?') } & \text { ('really cook } \\
& \text { around there' } \\
\text { a. bik-a-pu-njí-di? } & \text { bik-a-ku-njí-d } \\
\text { b. bik-a-nji-pú-di? } & \text { bik-a-nji-kú-d } \\
\text { c. bik-a-di-pú-nji? } & \text { bik-a-di-kú-n } \\
\text { d. bik-a-di-njí-pu? } & \text { bik-a-di-njí-k } \\
\text { e. bi-ka-nji-dí-pu? } & \text { bik-a-nji-dí-k } \\
\text { f. bik-a-pu-dí-nji? } & \text { bik-a-ku-dí-n }
\end{array}
$$$$
\text { With LOC }-p u
$$$$
\text { ('really cook what }
$$$$
\text { around there') }
$$$$
\text { bik-a-ku-njí-di? }
$$$$
\text { bik-a-nji-kú-di? }
$$$$
\text { bik-a-di-kú-nji? }
$$$$
\text { bik-a-di-njí-ku? }
$$$$
\text { bik-a-nji-dí-ku? }
$$$$
\text { bik-a-ku-dí-nji? }
$$
With LOC - mu
('really cook what in
there')
bik-a-mu-njí-di?
bik-a-nji-mú-di?
bik-a-di-mú-nji?
bik-a-di-mú-nji?
bik-a-nji-dí-mu?
bik-a-mu-njí-di?

When the plural-honorific -ani and the imperfective -anga are available in the verb morphology such as given in (16) above, they can freely mingle with the locatives, -nji, and -di as illustrated in (17) below.

-anga and -ani may follow a locative, -nji and -di

(meanings (17a) 'cook what really on there?'; (17b-l) 'be cooking what really on there?')
a. bik-ani-pu-njí-di?
c. bik-anga-di-(a)ni-pú-nji?
e. bik-anga-nji-di-(a)ní-pu?
g. bik-ani-pu-nji-dí-(a)nga?
i. bik-a-di-ni-pu-njí-(a)nga?
k. bik-a-nji-di-ani-pú-(a)nga?

b. bik-anga-(a)ni-pu-njí-di?

d. bik-anga-di-nji-(a)ní-pu?

f. bik-anga-pu-di-njí-(a)ni?

h. bik-a-nji-(a)ni-pu-dí-(a)nga?

j. bik-a-di-nji-(a)ni-pú-(a)nga?

1. bik-a-pu-di-nji-(a)ní-(a)nga?

Thus, the data presented in (17) above show that CiTonga behaves like a few Bantu languages where what may have originally been an affix, as Muzale (1998) maintains, now shows signs of being a clitic, a particle that follow the inflectional suffixes (see Nurse and Philippson 2003; Katamba 1993). Note in (17b-l) above that when $\mathrm{V}_{1}$ belongs to a bonafide clitic and $\mathrm{V}_{2}$ belongs to -ani or -anga (e.g. ditani), $\mathrm{V}_{2}$ belonging to -ani or -anga gets deleted in order to resolve the hiatus. Compare this observation with one where $\mathrm{V}_{1}$ belongs to -ani or -anga and $V_{2}$ belongs to an extension in (24) below. $\mathrm{V}_{1}$ (of the plural-honorific suffix or the imperfective) gets deleted.

The fact that -ani and -anga are optionally encoded at EXT is evident where they mix freely with derivational suffixes (extensions) such as the reciprocal (18a), the passive (18b) ${ }^{12}$, the causative (18c), the applicative (18d) and the intensive (18e).

$$
\begin{aligned}
& - \text { anga and -ani mix freely with extensions } \\
& (-a n-=\text { RECP, }-i k-=\text { PASS, }-i s y-=\text { CAUS, }-i y-=\text { APPL, }-i s y-=\text { INT) }
\end{aligned}
$$

\footnotetext{
11 The morpheme - $d i$ most likely starts from the adverb náadi 'really' (e.g. ndi-ngu-bik-a náadi $\rightarrow$ ndi-ngubik-aa-di 'I really cooked').

${ }^{12}$ CiTonga has two passive derivational suffixes, $-i w$ - and $-i k$-. The former is not productive at all and it is found in lexicalized passives (cf. CiTumbuka where both $-i k$ - and $-i w$ - are still productive - See Phiri 1980:171; Chavula 2016:65ff). Note that $-i k$ - is polysemous as it is also used to derive stative or neuter, among others.
} 


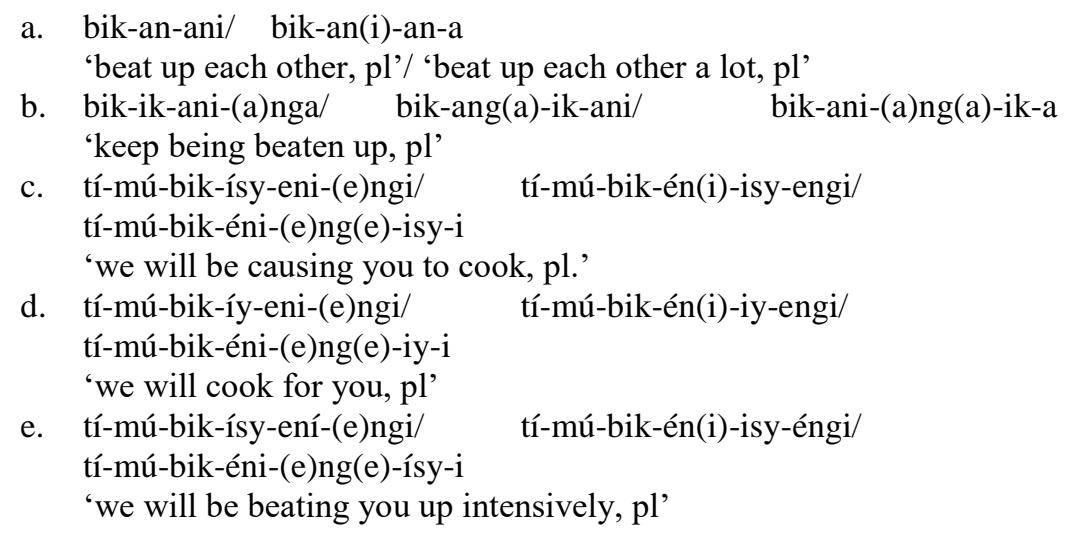

Thus, the data in (18a) show that the plural-honorific suffix can come after or precede the reciprocal morph. However, when -ani precedes -an-, $\mathrm{V}_{1}$ deletion leads to morphological and semantic neutralization as -ani now looks and mean exactly the same as the reciprocal -an-and that the output form now sounds like there is a reduplication of the reciprocal (to mean "cook each other a lot"). In (18b-e) the data show that the passive, the causative, the applicative and the intensive can freely be re-ordered with the imperfective and the plural-honorific morphemes. The fact that it is the $\mathrm{V}_{1}$ belonging to -ani or -anga, and not $\mathrm{V}_{2}$ belonging to derivational suffixes, that is deleted point to the fact that although -an $(i)$ and -ang $(a)$ can be encoded at EXT position, they are functionally different from them. They are also different from them in another aspect: Extensions have a VC shape while the bonafide shape of the plural-honorific suffix and the imperfective is VCV. They are also functionally different from POST-FINALS (clitics) which have a CV shape.

Perhaps another evidence that -ani and -anga are functionally different from bonafide extensions stems from progressive vowel harmony. Like in Chichewa discussed by Mchombo (1994) and Mtenje (1980, 1985, 1986, 1999), CiTonga has a progressive vowel height harmony system, where extension vowels are either /e/ or /i/ depending on the height of the root vowel. We illustrate this in (19) below.
Height vowel harmony in CiTonga
a. kam-isy-a
'cause to milk'
b. puw-isy-a
'cause to pound'
c. bik-isy-a
'cause to cook'
d. met-esy-a
'cause to shave'
e. wotch-esy-a
'cause to roast'

As we can see in the data in (19a-e) above, roots with the vowels $/ \mathrm{a} /, / \mathrm{u} / \mathrm{and} / \mathrm{i} /$, which are all nonmid vowels, take a causative extension that has a mid-vowel /e/. On the other hand, all roots with mid vowels /e/ and /o/ take the causative extension with the mid vowel /e/. Thus, the causative extension has two allomorphs (-isy-and -esy-), the choice being determined by the height properties of the root vowel. This type of vowel harmony is applicable to other extensions such as the passive (-ik-/-ek), the applicative (-il-/-el-), and the intensive (-isy-/-ésy-). In the case of -anga and -ani, however, vowel height harmony is never extended to them as shown in (20) below.

(20) Progressive vowel height harmony is never extended to -ani and -anga
a. kam-anga/kam-ani
'be milking'/ 'milk, pl'
b. puw-anga/puw-ani
'be pounding'/ 'pound, pl'
c. bik-anga/bik-ani
'be cooking'/ cook, pl'
d. met-anga/met-ani
'be shaving'/ 'shave, pl'
e. wotch-anga/wotch-ani
'be roasting'/ 'roast, pl' 
The data in (20) above show that the -ani and -anga are never affected by progressive vowel height harmony, an indication that they are indeed not functionally the same as the bonafide extensions.

\section{Conclusion}

The aim of this article was to examine the encoding of the plural-honorific suffix -ani and the imperfective -anga in CiTonga. We have argued that the status of both -ani and -anga is fluid. It prevaricates between EXT, FV and POST-FINAL. The commonest slot is the FV while EXT and POST-FINAL are used occasionally. Although these two morphemes are fluid like this, we have shown that they are functionally different from the bonafide extensions, final vowels and clitics.

\section{Abbreviations}

\begin{tabular}{|c|c|c|c|}
\hline APPL & applicative & MS & macrostem \\
\hline $\mathrm{C}$ & consonant & $\mathrm{N}$ & nasal consonant \\
\hline CAUS & causative suffix & NEG & negation \\
\hline DIST & distant & $\mathrm{OM}$ & object marker \\
\hline DS & derivational stem & PASS & passive \\
\hline DSs & derivational suffixes & PFV & perfective \\
\hline EXT & extension & PL & plural \\
\hline FUT & future & PLUR & $\begin{array}{l}\text { plural-honorific suffix } \\
\text { (pluralizer) }\end{array}$ \\
\hline $\mathrm{FV}$ & final vowel & PNFI & progressive near future itive \\
\hline IFS & inflectional final suffix & PST & past \\
\hline IMP & imperative & RECP & reciprocal suffix \\
\hline INF & infinitive marker & SBJV & subjunctive \\
\hline INFL & inflectional & SG & singular \\
\hline INT & intensive & SM & subject marker \\
\hline IPFV & imperfective & $\mathrm{TA}(\mathrm{M})$ & tense-aspect(-mood) \\
\hline IS & inflected stem & TRANS & transitional \\
\hline LOC & locative & $\mathrm{V}$ & vowel \\
\hline MOT & motive & & \\
\hline
\end{tabular}

\section{References}

Bernander, Rasmus. 2017. Grammar and grammaticalization in Manda: An analysis of the wider TAM domain in a Tanzanian Bantu language. Doctoral dissertation. University of Gothernburg, Gothernburg.

Bickmore, Lee, and Winfred Mkochi. 2018. OCP effects in Malawian CiTonga tone patterns. Nordic Journal of African Studies 27(4). 1-23.

Bickmore, Lee, and Winfred Mkochi. Forthcoming. Tonal absolute neutralization in Malawian CiTonga. Africana Linguistica XXV (2019).

Bryan, Margaret A. 1959. The Bantu languages of Africa. London, New York, Cape Town: Oxford University

Bybee, Joan, Revere D. Perkins, and William Pagliuca. 1994. The Evolution of grammar, tense, aspect, and modality in the languages of the world. Chicago: Chicago University Press.

Chavula, Jean J. 2016. Verbal derivation and valency in Citumbuka. Doctoral dissertation. Leiden University, Leiden.

Cheng, Chin-Chuan, and Charles W. Kisseberth. 1979. Ikolovere Makua tonology. Studies in the Linguistic Sciences 9(1). 31-63. 
Cheng, Chin-Chuan, and Charles W. Kisseberth. 1980. Ikorovere Makua tonology. Studies in the Linguistic Sciences 10(1). 15-44.

Cheng, Chin-Chuan, and Charles W. Kisseberth. 1981. Ikorovere Makua tonology. Studies in the Linguistic Sciences 11(1). 181-202.

Goldsmith, John. 1984. Tone and accent in Tonga. In Clements, George N., and John Goldsmith (eds.). Autosegmental studies in Bantu tone. 105-182. Dordrecht: Foris,

Comrie, Bernard. 1976. Aspect. Cambridge: Cambridge University Press.

Devos, Maud, and Daniel Van Olmen. 2013. Describing and explaining the variation of Bantu imperatives and prohibitives. Studies in Language 37(1). 1-57.

Downing, Laura J. 2001. Ungeneralizable generality in Ndebele. Studies in the Linguistic Sciences 30(1). 33-58.

Güldemann, Tom. 1999. The genesis of verbal negation in Bantu and its dependency on functional features of clause types. In Hombert, Jean-Marie, and Larry M. Hyman (eds.). Bantu historical linguistics. 545-587. Stanford: Center for the Study of Language and Information.

Guthrie, Malcolm. 1948. The classification of the Bantu languages. London, New York, Toronto: Oxford University Press.

Guthrie, Malcolm. 1967-71. Comparative Bantu. 4 vols. Farnbourough: Gregg International Publishers.

Hammarström, Harald, Robert Forkel, and Martin Haspelmath (eds.). 2018. Glottolog 3.3. Jena: Max Planck Institute for the Science of Human History (Available online at http://glottolog.org, last accessed on 2019-01-14).

Hyman, Larry M. 1989. Accent in Bantu: an appraisal. Studies in Linguistic Sciences 19(2). 115134.

Hyman, Larry M. 2007. Reconstructing the Proto-Bantu verbal unit: internal evidence. SOAS Working Papers in Linguistics 15. 201-211.

Hyman, Larry M. 2008. Directional asymmetries in the morphology and phonology of words, with special reference to Bantu. Linguistics 46(2). 309-350.

Hyman, Larry M. 2009. The natural history of verb-stem reduplication in Bantu. Morphology 19(2). 177-206.

Katamba, Francis. 1993. Morphology. London: McMillan Press Ltd.

Mchombo, Sam. 1994. The Syntax of Chichewa. Cambridge: Cambridge University Press.

Meeussen, Achille E. 1967. Bantu grammatical reconstructions. African Linguistics 61(3). 79-121.

Meeussen, Achille E. 2014. Tones of the subjunctive and the imperative in Bantu. Africana Linguistica 20. 15-38.

Mtenje, Alfred D. 1980. Aspects of Chichewa derivational phonology and syllable structure. MA thesis. Southern Illinois University, Carbondale.

Mtenje, Alfred D. 1985. Arguments for an autosegmental analysis of Chichewa vowel harmony. Lingua 66(1). 21-52.

Mtenje, Alfred D. 1986. Issues in the non-linear phonology of Chichewa. Ph.D. thesis. University College, London.

Mtenje, Alfred D. 2006. Alignment theory and prosody in Malawian CiTonga. Linguistic Analysis 32(3\&4): 327-365.

Mutaka, Ngessimo M. 1994. The Lexical Tonology of Kinande. Munich: Lincom Europa.

Muzale, Henry. 1998. A reconstruction of the Proto-Rutara tense aspect system. Doctoral dissertation. Memorial University of Newfoundland, Newfoundland.

Myers, Scott. 1987. Tone and the structure of words in Shona. Ph.D. thesis. University of Massachusetts, Amherst.

Myers, Scott. 1990. Tone and the structure of words in Shona. New York: Garland.

Myers, Scott. 1997. OCP effects in Optimality Theory. Natural Language and Linguistic Theory 15. 847-892.

Myers, Scott. 1998. AUX in Bantu morphology and phonology. In Hyman, Larry M. and Charles W. Kisseberth (eds.). Theoretical aspects of Bantu tone. 231-264. Stanford: CSLI Publications 
Ngonyani, Deo S. 2013. Surrogate imperatives in Bantu languages with postverbal negative particles. In Orie, Olanike Ola, and Karen W. Sanders (eds.). Selected Proceedings of the 43rd Annual Conference on African Linguistics. 177-187. Somerville, MA: Cascadilla Proceedings Project.

Nurse, Derek. 2008. Tense and Aspect in Bantu. Oxford: Oxford University Press.

Nurse, Derek and Gerard Philippson. 2003. The Bantu languages. London: Routledge.

Nurse, Derek and Gerard Philippson (2006). Common tense-aspect markers in Bantu. Journal of African Languages and Linguistics 27(2). 153-194.

Odden, David. 1996. The Phonology and Morphology of Kimatumbi. Oxford: Oxford University Press.

Phiri, Anaclet G. 1980. A description of derivational forms in Tumbuka. PhD thesis. University of Texas at Austin, Texas.

Rugemalira, Josephat. 2010. The -ag- TAM marker and the boundary between cliticization and affixation in Bantu. In Legère, Karsten, and Christina Thornell (eds.). Bantu languages: analyses, description and theory. 229-238. Köln: Rüdiger Koppe.

Schadeberg, Thilo C. 2003. Derivation. In Dereck Nurse, and Gerard Philippson (eds.). The Bantu languages, pp 71-89. London: Routledge.

Sebason, S. 1967. Der kohortativ "dual” und plural in den Bantusprachen. Zeitschrift der Deutschen Morgenlandischen Gesellschaft 3(2). 1502-1507.

Sommer, Gabrielle. 2003. Western Savanna (K, R). In Nurse, Derek, and Gerard Philippson (eds.). The Bantu Languages. 566-580. London: Routledge.

Tew, Mary. 1950. The peoples of the Lake Nyasa region. London, New York: Oxford University Press.

Turner, William Y. 1952. Tumbuka-Tonga-English Dictionary. Blantyre: Hetherwick Press.

Vail, Hazen L. 1973. Aspects of the Tumbuka Verb. Ph.D. thesis, University of Wisconsin, Wisconsin.

Van de Velde, Mark., and Johan van der Auwera. 2010. Le marqueur de l'allocutif pluriel dans les langues bantues. In Floricic, Franck (ed.). Essais de linguistique generale et de typologie linguistique offerts a Denis Creissels. 119-141. Paris: Presses de l'École Normale Supérieure.

Winfred Mkochi <wmkochi@cc.ac.mw>

University of Malawi

Centre for Language Studies

P.O. Box 108

Zomba, MALAWI. 